\title{
A HAZAI PÉNZÜGYI KULTÚRA FEJLESZTÉSÉNEK AKTUÁLIS FELADATAI
}

\author{
Kovács Levente - Nagy Ernö
}

\begin{abstract}
ABSZTRAKT
Tanulmányunk aktualitását az új típusú koronavírus-járvány hatására megváltozott környezet és a páneurópai Money Week idei programja adja. A Money Week

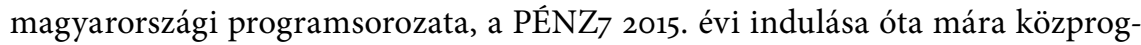
rammá vált, hiszen az iskolák és diákok többségéhez eljutott. Az elmúlt hét évben a bankszektor, a kormányzati szervek, az oktatási intézmények és civil szervezetek összefogásának hatására a rendezvény európai szinten is átütő sikere bizonyíték arra, hogy közösségi alapon is lehet sikeres pénzügyikultúra-oktatást, -fejlesztést indítani. A megváltozott környezet szükségesség teszi a pénzügyi kultúrát érintő képzés aktualizálását, új súlypontok kijelölését, aminek egyik lényeges eleme a pénzügyi digitalizációs folyamat eredményességét nagyban segítő technológiai háttér megismerése lehet.
\end{abstract}

JEL-kódok: A20, D10, G53

Kulcsszavak: pénzügyi kultúra, pénzügyi oktatás, pénzügyi tudatosság, lakossági megtakarítások, Magyarország

\section{BEVEZETÉS}

A pénzügyi kultúra kutatása az elmúlt években a közgazdaságtan lényeges területévé vált (OECD, 2020; Kovács-Terták (2019). Ebben azon feszítő ellentmondásnak a felismerése is szerepet kapott, miszerint a pénzügyi piaci modellek szereplői teljes informáltsággal bírnak, tökéletesen tudatosan cselekszenek, majd ez a viselkedés egy megközelítően tökéletes piaci működéshez vezet. Azonban éppen a pénzügyi kultúra empirikus vizsgálata tudott rámutatni arra, hogy a tökéletesen informált fogyasztó nem létezik. Sőt éppen ellenkezőleg, a pénzügyi kultúra fejlesztése is hozzájárul ahhoz, hogy a fogyasztók, a családok gyorsabban, teljeseb-

1 Kovács Levente fötitkár, Magyar Bankszövetség, tanszékvezető egyetemi tanár, Miskolci Egyetem. E-mail: kovacs.levente@bankszovetseg.hu.

Nagy Ernő vállalatirányítási igazgató, Fundamenta-Lakáskassza Zrt., PhD-hallgató, Miskolci Egyetem. E-mail: nagy.erno@fundamenta.hu. 
ben ismerjék fel anyagi helyzetüket, lehetőségeiket, a várható jövőbeni kiadásaikat, és majd - ezen szereplők tudatosabb viselkedéséből is következően - a piacok működése hatékonyabbá válhasson. A pénzügyi kultúra színvonala, a pénzügyi képzés léte és minősége valójában egyszerre hat az egyének jobb döntései, ezáltal magasabb életszínvonala és a közösség gazdálkodásának hatékonyabb müködésének irányába is. A pénzügyi kultúrát a teljes világra a Standard \& Poor’s 150 változó alapján elemzi (Kovács-Pásztor, 2022). Magyarország Kormánya 2017-ben, a 2007/2009-es pénzügyi, majd reálgazdasági válság után megváltozott pénzügyi és szabályozói környezetben, még a 2020/2021-es új típusú koronavírus-járvány előtt fogadta el a Pénzügyi tudatosság fejlesztésének stratégiáját (Magyarország Kormánya, 2017). Az elkészült stratégia hét évet ölelt fel 2017-től 2023-ig, támaszkodott az eddig elért eredményekre, programokra és azokra építve alakította ki a következő stratégiai célkitűzéseit:

1. A köznevelés rendszerén belüli valós pénzügyi edukáció kereteinek megteremtése, erősítése és általánossá tétele.

2. A tudatos pénzügyi magatartás alapjainak és a háztartások pénzügyi stressztűrő képességének erősítése.

3. Körültekintő pénzügyi döntéseket előmozdító szemlélet megteremtése és a tudatos pénzügyi fogyasztói magatartást támogató intézmények/infrastruktúrák létrehozása, valamint széles körű megismertetése.

4. A lakosság öngondoskodási szemléletének erősítése.

5. A pénzügyi termékekhez, pénzügyi alapszolgáltatásokhoz való hozzáférés és pénzügyi beilleszkedés (financial inclusion) mértékének növelése.

6. A korszerü, készpénzkímélő fizetési eszközök használatának ösztönzése.

7. Körültekintő hitelfelvétel támogatása.

A stratégiai célkitűzések között is látható, hogy rendkívül hangsúlyos a köznevelés szerepének erősítése. A kormányzati stratégiát egyébként a korábbi Gazdasági Együttmüködési és Fejlesztési Szervezet (OECD) International Network on Financial Education (INFE) és a legjobb nemzetközi gyakorlatok átültetésével, a magyar igények figyelembevételével dolgozták ki (Magyarország Kormánya, 2017:5). Az új típusú koronavírus-járvány által okozott, a mindennapi életünket mélyen felkavaró változások mérhető következményeinek elemzése jó alkalmat nyújt arra, hogy visszatekintsünk az elmúlt néhány év fejleményeire, és ennek tükrében határozzuk meg aktuális feladatainkat. Magyarországon a pénzügyikultúra-képzések résztvevőinek száma 2016 és 2020 között 461 681főről 1310352 före emelkedett (Németh, 2022). Az OECD/INFE legfrissebb felmérésének megállapítása szerint sajnos továbbra is érvényes, hogy „a vizsgált országokban alacsony a pénzügyi kultúra szintje" (OECD, 2020:7). Az OECD-tanulmány általános eredményeit ismertetve hazánk a vizsgált 26 ország közül a 14. helyezést 
érte el (OECD, 2020:16). Az összehasonlításunkba vont országok közül Ausztriát a közelsége és múltbeli összetartozásunkból fakadó, jó összehasonlíthatósága miatt, Csehországot pedig a közelebbi fejlettségi szintje és hasonló rendszerváltó történelmi múltja/kultúrája miatt választottuk ki vizsgálatunk tárgyául. A legfontosabb mutatókat a következő táblázat tartalmazza (1. táblázat):

\section{1. táblázat}

Pénzügyi müveltségi pontszámok (100-ra normalizálva)

\begin{tabular}{ccccc}
\hline Ország & $\begin{array}{c}\text { Pénzügyi } \\
\text { múveltségi } \\
\text { pontszámok }\end{array}$ & $\begin{array}{c}\text { Pénzügyi } \\
\text { tudás }\end{array}$ & $\begin{array}{c}\text { Pénzügyi } \\
\text { viselkedés }\end{array}$ & $\begin{array}{c}\text { Pénzügyi } \\
\text { attitúd }\end{array}$ \\
\hline Ausztria & 68,5 & 76,0 & 66,3 & 61,9 \\
Csehország & 62,0 & 64,9 & 59,1 & 62,9 \\
Magyarország & 58,8 & 65,5 & 49,9 & 65,1 \\
OECD-átlag & 62,0 & 65,8 & 59,2 & 61,6 \\
\hline
\end{tabular}

Forrás: saját szerkesztés az OECD (2020) 2. táblázata alapján (OECD, 2020:17)

Az OECD módszertanában a pénzügyi kultúra három eleme a pénzügyi tudás, a viselkedés és az attitűd (hozzáállás). Mint látható, a pénzügyi tudás kategóriában ugyan jelentősen alacsonyabb pontot értünk el, mint például Ausztria, de ebben megközelítőleg elérjük az OECD átlagát. Hasonlóan jól szerepel Magyarország az attitüd esetében, a valós pénzügyi viselkedés azonban - ezeknek ellentmondóan - alacsony értéket mutat. A pénzügyi viselkedés kategóriában az OECD-átlagnál $(59,2)$, illetve a csehországi $(59,1)$ és osztrák $(66,3)$ értékelésnél is lényegesen roszszabb eredményeket $(49,9)$ értünk el. Ez majdnem 10 százalékpontos lemaradás az OECD átlagához képest, ahol egyedül Olaszország ért el még nálunk is alacsonyabb eredményt $(46,3)$, miközben például a szomszédos Románia értéke 55,7. A pénzügyi kultúra komplex hatásmechanizmusából írásunkban négy általunk aktuálisan lényegesnek vélt témakört emelünk ki, melyek segítségével elemezzük a pénzügyi képzés szerepét és lehetőségeit.

\section{A PÉNZÜGYI KULTÚRA FEJLETTSÉGE POZITÍVAN HAT A PÉNZÜGYI STABILITÁSRA}

Meggyőződésünk szerint a pénzügyi kultúra fejlesztése nemcsak az egyes érintettek (kormányzat, bankok, fogyasztók) önérdeke, hanem a teljes nemzetgazdaság ellenálló képessége is jelentős mértékben növelhető, ha annak szereplöiként mélyebben megértjük, hogyan müködik a pénz a mindennapi életben (Csaba, 2019; Kovács-Sütő, 2020). A háztartások fenntartható gazdálkodási készségeinek fej- 
lesztésében központi szerepet kell kapnia a hosszú távú családi és nemzetgazdasági szintű pénzügyi ellenálló képesség (reziliencia) (ki)fejlesztésének.

Az elmúlt évek gazdasági fellendülésének nyomai tisztán látszanak a KSH (2021b) által publikált háztartási pénzügyi vagyonokon. Egyértelműen látható például, hogy 2016 és 2020 között jelentősen, 42,8 százalékkal nőtt a háztatások nettó pénzügyi vagyona, ami alapvetően kedvező jelenség. Az viszont már kedvezőtlen folyamat, hogy még ezt is meghaladó mértékben bővült a készpénz mennyisége. Mindez természetesen hasznos lehet a rövid távú háztartási sokkok elkerülése érdekében. A készpénzállomány-növekedés a vele járó társadalmi szintű költségnövekedés, továbbá a hosszú távú háztartási és nemzetgazdasági célok megvalósítása szempontjából viszont egyértelmüen káros (1. ábra):

\section{1. ábra}

\section{A háztartási szektor jövedelem- és tőkeszámlái (folyó áron, M Ft)}

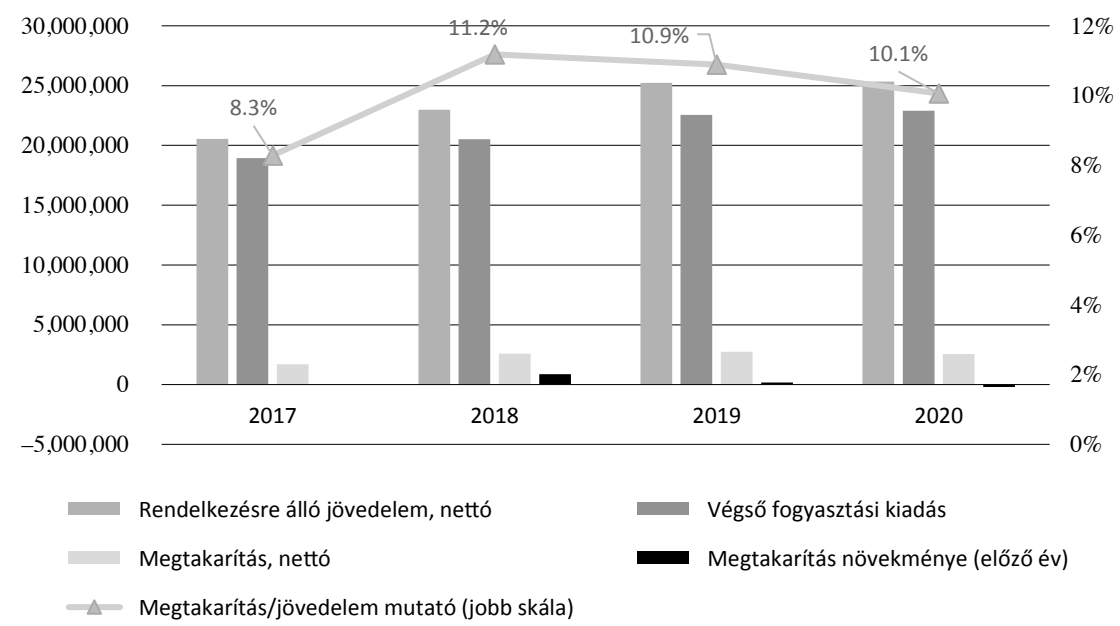

Forrás: a KSH (2021b) 21.1.1.32. táblázat adatai alapján saját szerkesztés

A fenti ábra az új típusú koronavírus-járvány statisztikailag mérhető hatását mutatja a lakossági megtakarításra (KSH, 2021b) vonatkoztatva. A tendenciákból látható, hogy a 2017-röl 2018-ra jelentősen emelkedő lakossági megtakarítások már 2019-ben megtorpantak. Ennek oka lehetett a hosszú évek óta növekedő gazdaság által indukált, magasabb fogyasztási szint. A járvány első és második hullámának hatására a háztartások jövedelme összességében nem csökkent (ebben szerepet játszhat a bevezetett jövedelempótlási intézkedések hatása is). A háztartások megtakarítása 2020-ban ugyan kissé visszaesett, de a jövedelemhez mért megtakarítás aránya továbbra is örvendetesen magas, és jelentősen meghaladja 
a 2017. évi értéket. Tehát a háztartások - bizonyára a korlátozó intézkedések hatására is - megtakarítással reagáltak, ami az óvatosság és a biztonságra törekvés egyértelmü jele.

\section{2. ábra}

\section{A háztartások nettó pénzügyi vagyona ( $\mathrm{Mrd} \mathrm{Ft})$}

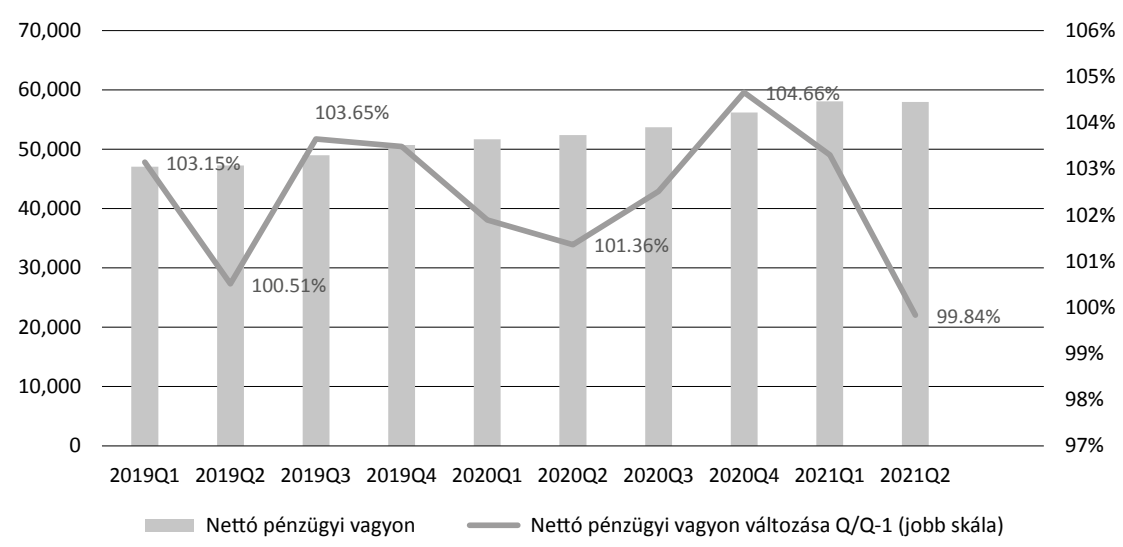

Forrás: az MNB (2021b) adatai alapján saját szerkesztés

A háztartások részletes, negyedéves pénzügyi számláinak elemzése mélyebb bepillantást is nyújt, amelyből láthatjuk, hogy az új típusú koronavírus-járvány különböző hullámai alatt is folyamatosan emelkedett a háztartások pénzügyi vagyona. Ez alól egyetlen időszak, a 2021-es év második negyedéve volt kivétel, amikor az azt megelőző negyedévvel való összehasonlításban mérsékelt csökkenés volt megfigyelhető, ez azonban még mindig meghaladja a 2020-as év utolsó negyedévének értékét. 
3. ábra

A háztartások készpénzvagyona, illetve annak aránya a nettó pénzügyi vagyonból ( $\mathrm{Mrd} \mathrm{Ft}$ )

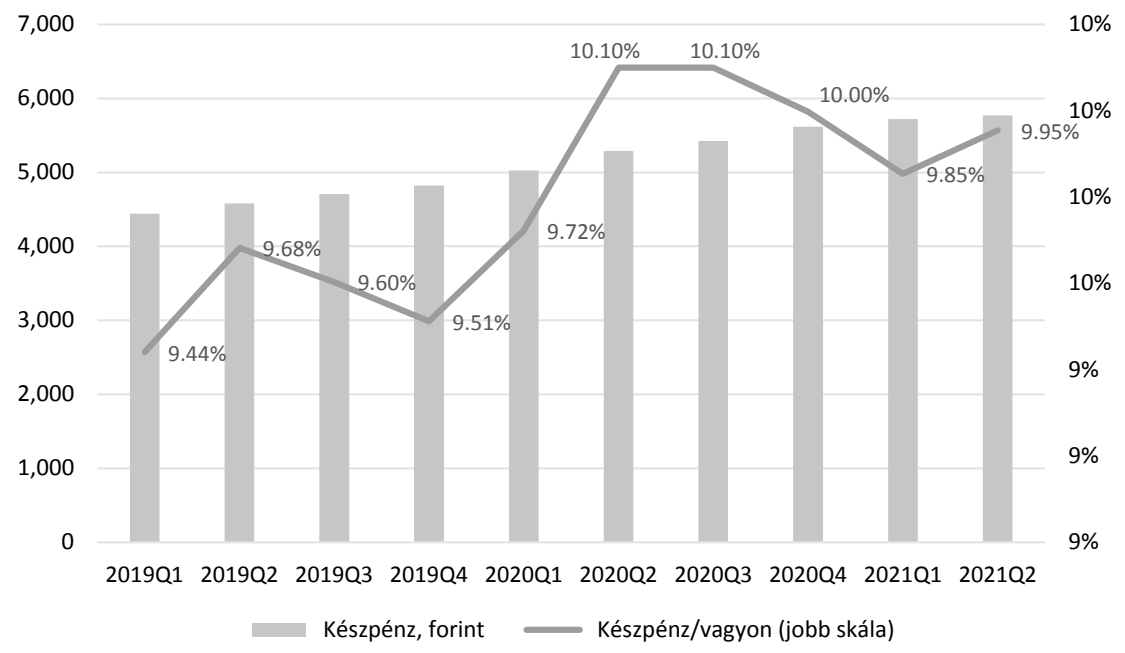

Forrás: az MNB (2021b) adatai alapján saját szerkesztés

A nettó pénzügyi vagyon pozitív növekedése, stabilitása mellett azonban az is jól látható, hogy 2020 első negyedévében, a pandémia első hulláma idején jelentősen megemelkedett a készpénz aránya a háztartások vagyonán belül. A mutató először csökkenni kezdett, majd ismét növekedésnek indult. Ennek egyik oka lehet a háztartások tartalékolási magatartásán belül a készpénz biztonságitartalék-szerepének megerősödése, valamint a feketegazdaságra visszavezethető készpénzarány növekedése is. A készpénz tartásának azonban ellentmond az elektronikus fizetés lehetőségeinek (kereskedői terminálok) bővülése és az egyre terjedő e-kereskedelem hatása. Összességében azonban kijelenthetjük, hogy a háztartásoknak a pandémia által kiváltott óvatos, tartalékolási magatartása egy kedvezőtlen irányba, a készpénzállomány növekedésének irányába fordult.

A nemzetgazdaság stabilitása szempontjából fontos a jövedelmek, megtakarítások, beruházások alakulásának és az éppen uralkodó gazdasági ciklus meghatározó jellegzetességeinek figyelemmel kísérése. Látjuk, hogy ezek változása egyrészt külső (exogén) okokból történik (például a pandémia okozta visszaesés), másrészt pedig belső gazdaságpolitikai döntések (például korábban a korlátlanul berobbanó svájci frank, vagy éppen euró alapú hitelezés) következménye is lehet. A makrogazdasági változásokhoz tudatos pénzügyi fogyasztói alkalmazkodás szükséges, az alkalmazkodáshoz pedig eltérő jellegü, lejáratú, hozamú, kockázatú 
lakossági termékek állnak rendelkezésre. A pénzügyi termékek és azok lényeges tulajdonságainak ismerete minden közoktatásból kikerülő diák számára fontos lenne, és a még keveset tapasztalt fiatalok számára is lényeges például a „hét szűk és hét bő esztendő” bölcsességének tudatosítása. Jól láthatjuk, hogy a gazdasági ciklusok szükségszerüen befolyásolják az egyéni lehetőségeinket is, de ehhez feltétlenül szükséges, hogy a fiatal felnőttek is számot vessenek az ô életükben várható, hosszabb távú egyéni vagy családi, gazdasági, jövedelmi ciklusok jellegzetességeivel is. A gazdálkodás jellemzően nem egyének, hanem háztartások, családok szintjén történik. A családok fejlődésének ciklusai azonban általános jellegüek, hiszen tudjuk, hogy a fiatalok közoktatásban való részvételét követi a leválás a szülökről, önállósodás, függetlenedés, párválasztás, gyerekvállalás, gyereknevelés, majd a gyerekek kirepülése és az öregkor örök körforgása. Ennek az ún. életciklus-megközelítésnek és főleg az ezzel járó, hosszú távú tervezésnek szükségszerüen teret kell kapnia a fiatalok nevelése során. Egyrészt kimutatható, hogy a jövedelmünk a munkával töltött életünk során először növekszik, majd általában stagnál, végül csökken (Kovács-Nagy, 2020). Másrészt köztudott, hogy a lakhatás elemi kérdés, tehát a lakáshoz jutás megoldása nem kikerülhető feladat, harmadrészt a gyerekek felnevelése az ingatlan mellett a legkomolyabb „befektetés” minden család életében, aminek a kezelése nagyfokú tudatosságot és előrelátást igényel. A nyugdíjas időszakra előretekintő megtakarítások szükségességét is könnyen beláthatja minden iskolás fiatal. Hazánknál fejlettebb gazdaságok példája is azt mutatja, hogy egyre kevésbé képes a hagyományos állami nyugdíjrendszer az időskorban kívánatos jóllétet fenntartani, ehhez szükséges az egyének előrelátása, ezt viszont egyre alaposabb pénzügyi tudással lehet elérni.

Ennek kapcsán feltétlenül lényeges a gazdasági ciklusok előrelátásának és kezelésének kérdése. A gazdasági tevékenység hullámzása természetes folyamat és a modern gazdaság szerves része, de nem teljesen egyértelmű az a tény, hogy az ezzel kapcsolatos tudatosság elemi fontosságú. Ez lehet egy olyan pont, ahol a tudás (knowledge) átfordulhat viselkedésbe (behavior). Egy tizenéves fiatal számára az élete tervezéséhez szükséges képesség a következő 30-50 év várható jövedelmének, kiadásainak célszerü megtervezése és átgondolása. Gyakori jelenség a hónapról hónapra való tengődés, többen juttatásaik kézhez vétele után teljes mértékben kiköltekeznek, és legkevésbé sem segítik elő a felelősebb pénzgazdálkodást költségvetés készítésével.

A hosszú távú tudatos viselkedés esetén lényeges kérdéskör például a kamatok hosszú távú hatása. Ugyan van tudomásunk arról, hogy a kamat általában hogyan müködik, hiszen ez elemi matematika, de lényeges azzal is szembesülni, hogy a kamatos kamat exponenciális hatása éppen hosszú távon, 15-30-40 év távlatában mennyire érzékenyen reagál a futamidő és a kamatláb változására. Erre nagyon jó példák kínálkoznak, hiszen többek között az MNB ösztönzésére beve- 
zetett fogyasztóbarát hitelek a fix kamatláb fontosságára, míg a harmadik alkalommal meghosszabbított hitelmoratórium a meg nem fizetett kamatok futamidő-hosszabbító hatására hívják fel a figyelmünket. Lakáscélú vagy nyugdíjcélú megtakarítást, öngondoskodási terméket akár egy-két évvel korábban is érdemes elkezdeni, mert a futamidő növelésének hatása jól érzékelhető lesz a megtakarított összegben.

A pénzügyi kultúra fejlettsége minden gazdasági szereplö közös érdeke. A fejlettebb pénzügyi kultúrával rendelkező háztartások nagyobb valószínűséggel kerülik el azokat a pénzügyi döntéseket, amelyek hátrányosak számukra, és ha magasabb szintű a társadalom pénzügyi kultúrája, akkor nagyobbak a rendelkezésre álló hazai megtakarítások is. A lakosság fejlettebb pénzügyi kultúrája így önmagában hozzájárul a pénzügyi rendszer stabilitásához. A pénzügyi közvetítő intézményeknek is alapvető érdeke a pénzügyi kultúra fejlesztése, hiszen az hozzájárul a magánszektor tudatos megtakarításának növekedéséhez, a fegyelmezett hitelhasználathoz és azon keresztül az egyes fogyasztó hitelképességének javulásához, összességében pedig a bankrendszer alacsonyabb kockázatú környezetéhez (Mihályi, 1997; Halmai, 2010; Poletaeva et al., 2019). A pénzügyi kultúra fejlesztése az állam érdeke is, hiszen magasabb szintű pénzügyi kultúra esetén kritikus helyzetekben/időszakokban sem emelkedik jelentősen az össztársadalmi vagy rétegigény az állam újraelosztási és stabilizációs felelősségvállalására, ami jótékony hatással bír a gazdaság minden szereplőjére, a helyreállításra és az ország versenyképességére.

\section{A HÁZTATÁSOK TUdATOSABB PÉNZGAZDÁLKODÁSÁNAK ERÖSÍTÉSE AKTUÁLIS FELADATUNK}

A pénzügyi tudatlanság felszámolása óriási feladat, a pénzügyi alapismeretek oktatása nagymértékben hozzájárulhat a fiatalok tudatosabb pénzgazdálkodásához. A pénzügyi ismeretek bővítése átalakítja az egyének és a háztartások gazdálkodását.

A pénzügyi ellenállóképesség (resilience) vizsgálata során is fontos kiemelni, hogy a szegénység és a pénzügyi műveletlenség között szoros a kapcsolat. A pénzügyi műveltségi szakadék csökkentése egyrészt kulcsfontosságú a leszakadó társadalmi csoportok elmaradásának csökkentéséhez, ami a vagyoni szakadékot mérsékli. Másrészt ez a fejlett pénzügyi piacokhoz való hozzájutást is képes növelni.

A saját pénzügyek figyelemmel kísérése jóval alacsonyabb értéket kapott hazánkban (46,6), mint az OECD átlagában $(64,5)$, miközben Csehország (64,1) és Ausztria $(83,2$ !) értékei is jóval magasabbak a magyarnál (OECD, 2020:37). Ez arra utal, hogy kevesebbet foglalkozunk a pénzügyeinkkel, mint amennyire szüksé- 
ges lenne. Ebben talán segítenek majd azok az applikációk (röviden appok), amelyek a legtöbb bank alkalmazásaiban ma már követhetővé, érthetővé teszik napi költéseinket. Látható, hogy ez nem objektív, nagy erőfeszítéssel megtanulandó információt, hanem viselkedési hiányosságot jelent (Pásztor, 2018). Az OECD felméréséből fontos azt is kiemelni, hogy a jövedelem elvesztése esetén a „pénzügyi védelem” (cushion) az összehasonlításba vont környező országok értékeinél jelentősen alacsonyabb (OECD, 2020:43).

\section{2. táblázat}

A pénzügyi védelem mértéke a jövedelem elvesztése esetén (\%)

\begin{tabular}{cccccc}
\hline Ország & $\begin{array}{c}\text { Egy hét } \\
\text { körül }\end{array}$ & $\begin{array}{c}\text { Egy hónap } \\
\text { körüll }\end{array}$ & $\begin{array}{c}\text { Három } \\
\text { hónap körüil }\end{array}$ & $\begin{array}{c}\text { Hat hónap } \\
\text { vagy több }\end{array}$ & $\begin{array}{c}\text { Nem } \\
\text { tudom }\end{array}$ \\
\hline Ausztria & 12,2 & 22,9 & 21,4 & 33,8 & 9,7 \\
Csehország & 16,0 & 22,2 & 23,0 & 26,8 & 12,0 \\
Magyarország & 34,8 & 27,8 & 15,5 & 11,5 & 10,4 \\
OECD-átlag & 20,0 & 24,6 & 18,0 & 23,2 & 14,2 \\
\hline
\end{tabular}

Forrás: saját szerkesztés az OECD (2020:43) adatai alapján

Amennyiben a legalább három hónapot elérő értékeket összeadjuk, akkor hazánkban csak a megkérdezettek körülbelül negyede (27 százaléka) rendelkezik elegendő pénzügyi biztonsággal három hónapos időtartamra, míg a háztartások mintegy fele legfeljebb három hónapig bírná ki külső források bevonása nélkül. Ez túlzottan nagy háztartási szintű sérülékenységet jelez, ami bizonyára ismét nemcsak a pénzügyi tudás, hanem a viselkedés és magatartás következménye is. Az MNB jelentése sajnos hasonló képet mutat: a teljes népesség 60 százaléka egy hetet meghaladó, de három hónapot el nem érő ideig tudná jelenlegi életszínvonalát jövedelem nélkül, a tartalékaiból fenntartani (1. MNB, 2021a:43. ábra). 
4. ábra

A háztartások megtakarítási szintjei

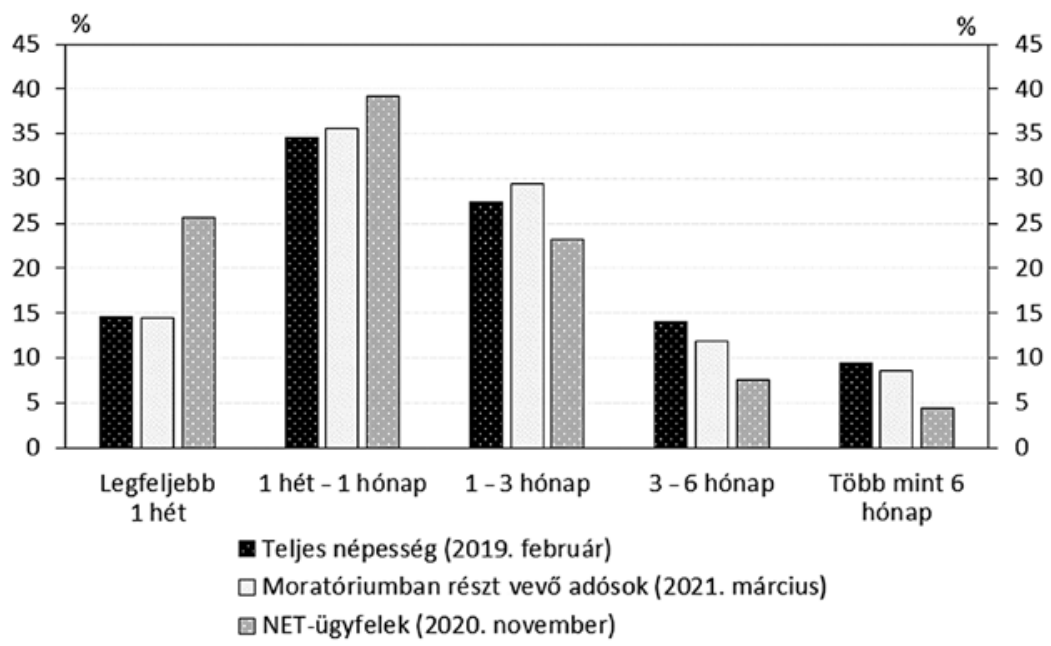

Megjegyzés: Ha a háztartásában minden kereső elveszítené az állását, mennyi ideig lenne képes fenntartani a jelenlegi életszínvonalát? (In EU SILC, MNB Nemzeti Eszközkezelő kutatás, 2020. november, MNB Moratórium kérdőíves felmérés, 2021. március.)

Forrás: MNB (2021a)

A további szempontok vizsgálata alapján Magyarországon nagyon alacsony a hosszú távú pénzügyi célokkal rendelkezők aránya (35,2\%), miközben az OECD $(44,9 \%)$ és Ausztria (53,1\%) átlagai a hazainál jóval magasabbak, Csehország értéke viszont még nálunk is alacsonyabb $(32,8 \%)(\mathrm{OECD}, 2020: 46-47)$. Korábban már említettük az életciklus-alapú tervezés fontosságát, Magyarország ezen OECDértékelése pedig egészen komoly feladatokat jelöl ki a hazai döntéshozók számára. Hazánkban alacsony az aktív megtakarítók aránya is $(51,3 \%)$, míg az OECD átlaga $68,9 \%$. Ausztria $(87,8 \%)$ és Csehország $(88,8 \%)$ értékei teljesen más nagyságrendet és kategóriát jeleznek. Ezen értékek bizonyára összefüggnek a jövedelmeknek a gazdaságilag aktív népességen belüli megoszlásával, hiszen hazánkban összességében jelentősen növekedett a lakossági megtakarítások mértéke a 2. ábra alapján, ami arra utalhat, hogy az eleve magasabb jövedelmi kategóriában jobban halmozódott a vagyon, tehát a vagyoni és jövedelmi koncentráció tovább erősödhetett. Figyelemre méltó, hogy Csehország megkérdezettjei láthatóan hosszú távú célok nélkül is megtakarítanak. Ez okozhatja mindkét országban a fenti 3. táblázatban bemutatott, a magyarországinál jóval hosszabb időtartamú pénzügyi védettséget a jövedelem elvesztésének esetében (Csehországban és Ausztriában a lakosság mintegy fele 3-6 hónapig terjedő pénzügyi védelmet jelölt meg). 
Németh és munkatársai (2016) a hazai pénzügyi személyiségtípusok több mint 3 ezer elemü mintájának statisztikai elemzésével kimutatták, hogy „A »rend értéket teremt« dimenzió, valamint a »tervezők« dimenzió egyértelműen azok, amelyek olyan tulajdonságokat foglalnak magukba, hogy azok alapján a legnagyobb valószínűséggel rendelkezik valaki pozitív, vagyis jónak ítélhető pénzügyi személyiséggel. A tervezés, a hosszú távú szemlélet, a pénz megítélése az érte elvégzett munkán keresztül mind-mind pozitív jelenség a pénzügyi személyiség szempontjából" (Németh et al., 2016:169-170).

A pénz alapvetően jó tulajdonsága, hogy segítségével könnyen megtakaríthatunk, ennek ellenére hazánkban megfigyelhetjük a „jobb ma egy veréb, mint holnap egy túzok" mentalitást, ami a gondolkodásmódban nagyon magas diszkontráta meglétére utal. Mindez azt jelenti, hogy sokan azonnal elköltik a rendelkezésükre álló forrásokat (néha még annál többet is), és nem számolnak a jövőbeli várható kiadásokkal. A jövőbeni szükségletek tudatosítása segítene a rövid távú pénzügyi zavarok elkerülésében, ugyanis éppen a nem tervezett rövid távú kiadások jellemzően legdrágább idegen forrásokból történő kiegyenlítése vezethet gyors, nehezen kontrollálható és jelentős eladósodáshoz.

A tudatosabb háztartási pénzgazdálkodás része a készpénz szerepének korrekciója: a mai gazdaságban a készpénz célszerűen már nem megtakarítási, vagyonfelhalmozási eszköz, sőt a fizetési tranzakciók egyre kisebb részét kell csak ellátnia. A használatban lévő készpénzállomány tudatos befektetése még komoly lehetőségeket kínál a piac és az állam számára is. Az elektronikus fizetési formák megbízhatóságának, a 2020-ban elindított Azonnali Fizetési Rendszer (MNB, 2020) lehetőségeinek kommunikálása tovább növelheti a korszerü elektronikus fizetési formák használatába vetett bizalmat. Az új típusú koronavírus-járvány hatására nőtt az elektronikus kereskedelem aránya, ami még inkább szükségessé teszi a háztartások készpénztartásának csökkentését. A pénzügyi jóllét az OECD felmérésében ezen dimenziókra épül: pénzügyi kontroll, pénzügyi védettség jövedelemkiesés esetén és pénzügyi célok megléte. Ezen területek tekintetében jelentős út áll még előttünk.

\section{SZÜKSÉGES AZ ISKOLAI PÉNZÜGYI OKTATÁS ERŐSÍTÉSE}

Sok gyermek hiszi azt, hogy a pénz magától keletkezik, a szüleinek korlátlanul van belőle. Nem ismerik, így nem is veszik figyelembe a családi költségvetés korlátait. Az említett OECD-felmérés egyik megdöbbento megállapítása, hogy „a fiatalok (18-29 év között) pénzügyi ismeretei és pénzügyi attitüd értékei következetesen és szignifikánsan alacsonyabbak a többi korcsoporthoz képest” (OECD, 2020:64). Ez megerősíti azt a javaslatunkat, hogy a közoktatásban célszerű ezen ismerete- 
ket, illetve azok nagyobb részét a diákok rendelkezésére bocsátani - vagy legalább a nyitottságot és a lehetséges megoldások megkeresésének képességét megteremteni. A pénzügyi műveltség fejlesztését biztos oktatói ismeret nélkül gyakran elhanyagolják a képzések során. Véleményünk szerint ebben nem elegendő csak a szüken vett tények ismeretére (tudásátadás) koncentrálni, hanem a tényleges viselkedés fejlesztése, a megszokott reakciók átalakítása is szükséges.

Egyébiránt a pénzügyi tudás (knowledge) mérésekor az OECD a módszertanában az alábbi szempontok megértésére támaszkodott:

i) a pénz időértéke,

ii) a hitelre fizetett kamat,

iii) egyszerű kamatszámítás,

iv) egyszerü és kamatos kamat számítása,

v) a kockázat és hozam összefüggései,

vi) az infláció definíciója,

vii) a kockázat diverzifikációja (OECD, 2020:20).

A fenti szempontok értékelésében a hazai eredmények kis eltérésekkel (1,5-3,5 pont eltérés a 100 fokú skálán) mozogtak az OECD átlaga körül, ami alapvetően jónak tekinthető. Egy kiugró eltérés azonban megfigyelhető. Az egyszerű és kamatos kamat számításának megértése során az OECD átlaga 28,8 pont volt, míg a hazai érték 18,3 pont, eközben Csehország 21,0, míg Ausztriában 49,o(!) pontot ért el. Ez olyan lényeges elmaradás, amely a fentiekben már érintett, hoszszú távú tervezés megértésének hiányára utalhat. A hosszú távú célokkal szemben állnak a rövid távú fogyasztási megfontolások, és eközben nem világos, hogy a hosszú távú célok elérése csak ennek megfelelő hosszú távú viselkedés kialakításával lehetséges. Sajnos, mind ismerjük azokat a személyes eseteket, ahol például az adott személy vagy család lakhatásának minőségét jelentősen meghaladja a birtokolt jármüvek, elektronikai eszközök és jólléti kiadások értéke.

„A fiatalabbak ma sokkal összetettebb pénzügyi helyzettel szembesülnek, mint korábban a szüleik” - idézi a Financial Times Annamaria Lusardit: „Megrendültem, hogy milyen sok fiatal érdeklődik a kriptovaluták iránt. A pandémia közben az emberek többet tesznek félre, és egyúttal riasztó azt látni, hogy magasabb hozamokat akarnak elérni anélkül, hogy felfognák, eközben milyen kockázatokat vállalnak" (FT, 2021a.). A kriptovalutákba történő befektetés iránti felfokozott érdeklődés (hype) szöges ellentétben áll a fent bemutatott, szélesen elterjedt készpénztartással. A készpénz csökkenő szerepének elemzése így a pénzügyi oktatás része kell, hogy legyen.

A pénzügyi oktatás különböző nemzetközi megvalósulási formái eltéréseket mutatnak (Terták, 2022). A pénzügyi müveltség oktatása több úton is lehetséges. 
Ismert út, amikor a klasszikus szaktárgyak tanrendjébe épülnek be konkrét példákon keresztül a pénzügyi műveltség elemei. Példa lehet erre matematikából a kamatos kamat müveletének felhasználása a hosszú távú megtakarítási és hiteltermékek ismertetésére. Az exponenciális görbe tengelyei azonnal életre kelnek, és szemléletes példává válnak. Gazdaságtörténeti eseményekhez lehet kötni az infláció vagy a gazdasági válság - és ezzel a pénzügyi kockázatok - oktatását. Akár etikaóra témája lehet a csőd, magáncsőd megvitatása. Informatikaórán ismertetni lehet az elektronikus fizetési eszközök (például terminál, kártya, mobilalkalmazás) müködését, a mögöttük álló lenyügöző pénzügyi infrastruktúrát.

Egy másik megközelítés lehet a tisztán pénzügyi, gazdasági jellegű oktatás mint szakóra kiterjesztése. Középiskolai vagy gimnáziumi tanárokkal folytatott beszélgetések során hamar felmerülhet az a kérdés, hogy vajon az egysejtüek szaporodása, a szögfüggvények, az idegen nevek helyesírása, a mitológiai történetek, a versmértékek vagy a bankszámlanyitás szempontjainak ismerete lesznek-e a fontosabbak az életben egy mai középiskolás diák számára. Egy ilyen kérdésfelvetés természetesen nem a természettudományi és bölcsésztudományi szakórák ellen irányul, másrészt viszont érzékelhető a diákok kíváncsisága, nyitottsága a gyakorlati, közöttük a pénzügyi problémákra, szempontokra. Mivel a hétköznapi pénzügyek oktatásának nincs még hosszú távú hagyománya hazánkban, ezért lényeges a $\mathrm{PÉNZ7}$ jelenlegi összefogáson, önkéntességen alapuló működtetése, de szükséges az oktatás kiterjesztésének/átalakításának a vizsgálata is.

Lusardi $(F T, 2021 a)$ is elkezdett Olaszországban egy iskolai oktatási projektet, ahol a diákokkal vállalkozási ötletek megvitatását, pénzügyi tervek kidolgozását végezték el. Idősebb diákok zöldséget állítottak elő a helyi piacra, hogy megértsék a gazdálkodás jellegét. Mások pedig páronként magyarázták egymásnak és kérdezték ki a másiktól a pénzügyi termékek jellemzőit, működését. Lusardi ennek az alapján meg van győződve arról, hogy a pénzügyi műveltség oktatása kritikus fontosságú a fiatalok számára: „Nem mindegyik szülő fog beszélgetni a gyerekeivel ezekről a témákról, és gyakran maguk a szülők sem túlzottan tájékozottak ezeken a területeken" (FT, 2021a).

Lényeges annak a rögzítése és gyakori hangsúlyozása, hogy jól működő nemzetgazdasághoz nem elegendő a kiművelt mérnökök, orvosok, pedagógusok és egyéb további szakmák sokasága, hanem tudatos, tájékozott pénzügyi fogyasztókra is szükség van. Különösen igaz ez akkor, amikor az új típusú koronavírus-járvány következményeként a pénzintézetek és a gazdaság felgyorsult digitalizációja, a fintech- és big tech cégek betörése a pénzügyekbe minden eddiginél könnyebbé teszi a pénzügyi müveletek elvégzését (itt megint felhívjuk a figyelmet, hogy ennek ellentmond a készpénzállomány további növekedése). A pénzügyi szempontból tapasztaltabb felnőttek, de az informatikában járatosabb fiatalok számára sem egyszerü annak az áttekintése, hogy időközben a pénzünkkel éppen mi is 
történik. A komplex pénzügyi termékek és a modern, fejlett alkalmazások elfedik a tényleges tartalmak, kockázatok megértését.

A pénzügyi ismeretek oktatása ahhoz hasonlítható, ami az életben sokkal nagyobb hasznot hoz a diákoknak, mint néhány lecke megírása vagy mint az érdeklődési körből kikerült ismeretek kötelező jellegü betanulása. A pénzügyek ismeretére egész életükben szükségük van/lesz, és a fiatalok célzott megszólításának egyik indoka, hogy az iskoláskort követően egyetemlegesen sokkal nehezebben érhetők el az egyes társadalmi korosztályok.

Amellett érvelünk tehát, hogy nem a pénzügyi termékek részleteinek ismerete, hanem sokkal inkább az összefüggések megértése és azok tudatos, napi használata segíti a fiatalok tudatos pénzügyi viselkedésének fejlődését. A hazai tudás (knowledge) mint alap az OECD felmérése alapján ugyan viszonylag erős, de a gyakorlatban ezt felhasználó viselkedés (behavior) még fejlesztendő. Mindez azért lenne elemi fontosságú, mert a pénzügyi digitalizációs folyamatot visszavetheti, de mindenképpen lassíthatja az, ha a felhasználók nem értik, illetve bizonyos szintig nem tudják megérteni a mögöttes technológiát, illetve annak müködését. Amennyiben minimális vagy elhanyagolható szintű ismeretekkel rendelkeznek, szkeptikusok, bizalmatlanok maradnak, és nem vagy csak vonakodva veszik majd át a digitalizáció eredményeit.

\section{5. ÖSSZEGZÉS ÉS KÖVETKEZTETÉSEK: A PÉNZÜGYI MÜVELTSÉG A PÉNZÜGYI SZABADSÁG ELÖFELTÉTELE}

A „pénzügyi szabadság” megfogalmazható így: az egyén tudatában van annak, hogy egészen pontosan mit szeretne az élete során elérni a pénzügyek területén, ismeri az ehhez rendelkezésre álló eszközöket, és tudatosan cselekszik a céljai elérése érdekében és ezen eszközök használatában is. A pénzügyi tudatosság nem öncél, hanem a saját vágyaink elérésének eszköze. A pénzügyi alapismeretek önbizalmat is adnak a pénzhez kapcsolódó problémáink megoldásához.

Egyértelmüen látszanak azok a társadalmi csoportok, akik különösen sérülékenyek a pénzügyi tudatosság tekintetében. Korábban kiemeltük a fiatalok sérülékenységét (OECD, 2021), de az OECD (2020) tanulmánya szerint kimutatható a nők sérülékenysége is: „A teljes mintában éppúgy, mint az OECD-országokban is, a férfiak pénzügyi müveltsége érzékelhetően magasabb. Azon válaszadók, akik digitális eszközöket vagy szolgáltatásokat használtak, következetesen és szignifikánsan magasabb pénzügyi műveltségi, tudásbeli, viselkedési és jólléti értékeket értek el.” (OECD, 2020:57-58). A jelentés nemek közötti különbségére tett eredményére további vizsgálatok szükségesek, mert több más kutatás érdekes módon azt 
állítja, hogy nincs különbség a nők és a férfiak között. A Financial Times és Ipsos Mori felmérése $(F T, 2021 b)$ hasonló eredményekre vezetett: a pénzügyi tudatosság mértéke, az életkor, valamint a hátrányos helyzet is mind jelentősen befolyásolta a pénzügyi viselkedés kapcsán feltett négy kérdésre adott válaszokat. A kevésbé műveltek, hátrányosabb helyzetben lévők és fiatalabbak rendre rosszabb válaszokat adtak az alábbi felvetésekre:

1. A jelzálogot kivéve nincs tartozásom.

2. Minden hónap végén visszafizetem a hitelkártya-tartozásomat.

3. Fontos a nyugdíj-megtakarítás.

4. Fontos a vészhelyzetekre történő megtakarítás.

\section{5. ábra}

\section{A pénzügyi magatartás eltérései a brit társadalomban}

A pénzügyi magatartás eltérései Angliában a demográfiai jellemzők alapján \%, aki egyetért a következő állításokkal

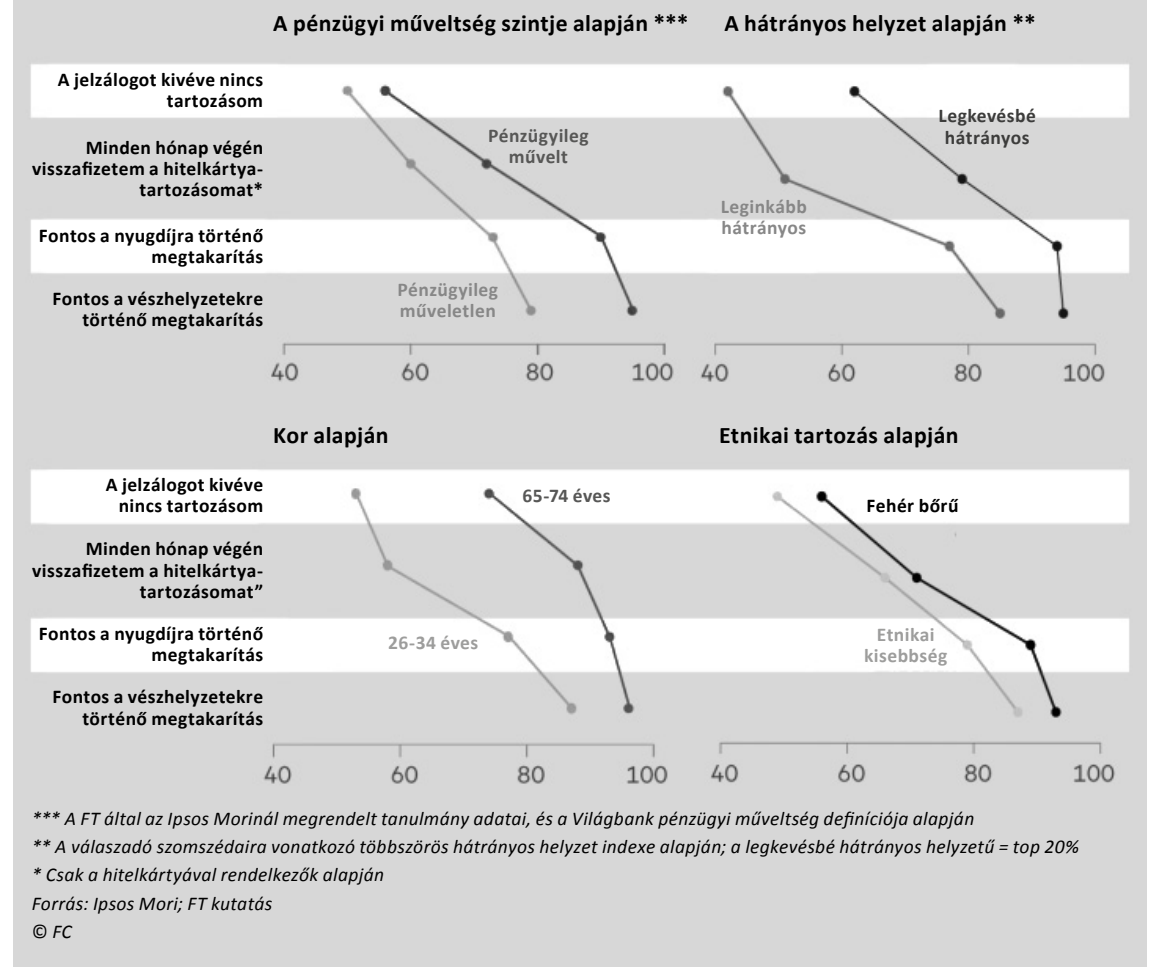

Forrás: Financial Times (2021b) alapján saját fordítás 
Nagyon lényeges a családi minták, a szülők, a nagyszülők és a rokonok viselkedésének megfigyelése. Meggyőződésünk szerint ez erős alapot adhat a fiatalok számára a saját tudatosságuk kialakításához. Egy tágabb és nagyobb családban jellemzően eltérő minták figyelhetők meg a tanulás, ennek következtében a kialakuló jövedelem, a megszerzett jövedelem elköltése, így a fogyasztás, a különböző célokra történő megtakarítás, önerő képzése, saját vagy vállalkozási célú beruházások tekintetében is. Ez is a tanulás nagyon jó útja lehet, ha a fiatalok képesek a látott, megtapasztalt viselkedési mintákat felismerni és tudatosítani. A szülők mellett az iskola is aktív szerepet vállalhat jó és rossz minták felismertetésével, bemutatásával és a kapcsolódó tudás átadásával.

A pénzügyi tudás szerepét már kiemeltük: nem elsősorban a részletek, hanem a lényeges összefüggések megismerése fontos. A hozam és kockázat, a biztonság, a rövid és hosszú távú termékek, a hitelfelvétel feltételei és következményei azok a lényeges témák, amelyekkel aztán az életben szembesülnek a diákok. Ez a zsebpénz, a nyári munka jövedelmének tudatos elköltésével vagy éppen megtakarításával kezdődik, majd ezt követi a banki számlaválasztás, a digitális fizetési formák nehéz (és jellemzően nagyon hosszú távú kihatással bíró) kérdése, majd az első diákhitel felvételének dilemmája. Idetartozhat a saját vállalkozás alapításának (üzleti terv, cégalapítás, vállalkozói számla megnyitása, adózás alapkérdései) ismeretköre is. Ezt pedig rögtön követi a párválasztás után az első saját lakás megszerzése és a kapcsolódó állami transzferek (a jelenlegi rendszerben például a babaváró, a családi otthonteremtési kedvezmény stb.) feltételeinek nagyon komplex kérdésköre. A pénzügyi mủveltség oktatásához hasznosak a fent említett matematikai, történelmi, etikai tudások, az érettebb korral elérhető szülői, családi gyakorlatok megszerzése, az esetleges első diákmunka jövedelemszerzésével kapcsolatos saját tapasztalatok, egyúttal égetőbbek a közelgő felsőoktatási tanulmányok esetleges gazdasági kényszerei (leválás a szülőkről, albérlet, tandíj). Ezen túlmenően a felsőoktatásban már csak a fiatal generáció egy szerényebb része érhető el, így a középfokú oktatás derekánál lehet az az életkor, amikor a diákok már nyitottak, befogadók, és van elég tapasztalatuk ezen tudás megszerzéséhez.

A pénzügyi tudás megszerzésének támogatása így az esélyegyenlőség megteremtésének eszköze is. Sok gyermek nem örököl vagyont, sőt még szülői segítséget sem kap a pénzügyek területén. A magasabb szintủ pénzügyi oktatás viszont maradandó érték lehet mindenkinek. Az esélyteremtő állam segít a fiataloknak abban, hogy önállóan, tudatosan léphessenek ki a piacra, hogy megfontoltan és a saját életcéljaikat támogatva viselkedjenek, elősegítve ezzel a nemzetgazdaság hatékonyabb müködését is. A pénzügyeikben tudatosan viselkedő fiatalok kevesebbszer botlanak meg, kevesebb állami segítségre szorulnak, alaposabb napi döntéseikkel elősegítik a pénzügyi szolgáltatók magasabb szintű kiszolgálási minőségét, erősítve közöttük a versenyt. Ez egy mindenki számára nyerő (ún. 
win-win) helyzetet eredményez a pénzügyi fogyasztó fiatalok, a pénzügyi szolgáltató intézmények és az állam szempontjából is.

A pénzügyi szabadság felelősséggel jár a fiatalok számára is. Ez a szabadság azonban hozzásegíti őket álmaik eléréséhez, és közben mindenkit egy hatékonyabb nemzetgazdaság kialakulásához. Mind a piaci szereplők, mind az állam feladata a pénzügyi szabadság feltételeként a pénzügyi tudatosság megteremtésének támogatása. A fentiek alapján is szükségesnek látjuk, hogy a gyakorlati pénzügyi ismeretek és pénzügyi viselkedés oktatása a többi társadalom- és természettudományi tantárgy mellett önálló tantárgyi helyet kapjon a középfokú oktatásban.

\section{HIVATKOZÁSOK}

ÁSZ (2021): A lakossági megtakarításokra és ezek államadósság finaszírozásba való bevonhatóságára ható tényezők. https://www.asz.hu/storage/files/files/elemzesek/2021/E3213_Lak_megtak_ET_ vegl_ism2 sszef__z__tt_SKO.pdf?ctid=1307.

Béres DÁNIEL - Huzdik Katalin (2012): A pénzügyi kultúra megjelenése makrogazdasági szinten. Pénzügyi Szemle, 57(3), 322-336, HU ISSN o031-496-X.

Németh, Erzsébet - Béres, Dániel - Huzdik, Katalin (2015) The Attitude of Young Hungarian Adults to Loans. International Journal of Business and Social Science, 6(4), 63-73. ISSN 2219-1933, http://real.mtak.hu/id/eprint/3909o.

Csaba LÁszLó (2019): A költségvetési és bankunió: vízválasztó a többsebességes EU-ban In: HALMAI PÉTER (szerk., 2019): Tagállami integrációs modellek: A gazdasági kormányzás új dimenziói az Európai Unióban. Budapest: Ludovika Egyetemi Kiadó, 167-181. https://nkerepo.uni-nke. hu/xmlui/bitstream/handle/123456789/14744/web_PDF_Tagallami_integracios_modellek. pdf? sequence $=1 \#$ page $=168$.

Csorba LÁszló (2020): Pénzügyi kultúra és pénzügyi műveltség, a pénzügyi magatartás meghatározó tényező. Pénzügyi Szemle, 65(1), 67-82. ISSN o031-496X, http://doi.org/10.35551/ PSZ_2020_1_6.

Czakó Ágnes - Husz Ildikó - SzÁntó Zoltán (szerk., 2011): Meddig nyújtózkodjunk? A magyar háztartások és vállalkozások pénzügyi kultúrájának változása a válság időszakában: gazdaságszociológiai műhelytanulmányok. Budapest: BCE Innovációs Központ Nonprofit Kft.

Financial Times (2021a): 'We need people to know the ABC of finance': facing up to the financialliteracy crisis. https://www.ft.com/content/b6a8107c-99f f-4a43-8adc-9686e6bd6o3e?shareType=nongift (letöltve: 2021.10.12.).

Financial Times (2021b): Best of FT Money 2021: Why financial literacy is a passport to financial freedom. https://www.ft.com/content/80480742-9853-4144-9c91-238021414bc8?shareType=nongift (letöltve: 2021.10.12.).

Halmai, P. - VÁsÁRY, V. (2011) Crisis and economic growth in the EU. Medium and long-term trends. Acta Oeconomica, 61(4), 465-485. ISSN ooo1-6373, http://dx.doi.org/10.1556/AOecon.61.2011.4.4

Kovács Levente - NAGY ERnő (2020): Életciklus és törlesztőrészlet. A reálértékben állandó törlesztőrészlet és életciklus-jövedelem alkalmazhatósága a lakáshitelezésben. Közgazdasági Szemle, LXVII. évf., október, http://doi.org/10.18414/KSZ.2020.10.1029.

KovÁcs LeVENTE - SÜTő ÁGNES (2020): Megjegyzések a pénzügyi kultúra fejlesztéséről. Gazdaság és Pénzügy, 7(1), 137-146, http://doi.org/10.33926/GP.2020.1.6.

Kovács Levente - PÁsztor Szabolcs (2022) A pénzügyi kultúra az európai oktatásban. Gazdaság és Pénzügy, 9(1), 50-67, http://doi.org/10.33926/GP.2022.1.3. 
Kovács, Levente - Terták, Elemér (2019): Financial Literacy - Theory and Evidence. Bratislava (Slovakia): (2019) Verlag Dashöfer, https://bankszovetseg.hu/Public/publikacio/Financial\%2O literacy.pdf.

KSH (2021a): 3.7.5. A háztartások pénzügyi vagyona. https://www.ksh.hu/docs/hun/xstadat/xstadat_ evkozi/e_qseoo8c.html.

KSH (2021b): 21.1.1.32. A háztartási szektor jövedelem- és tőkeszámlái [folyó áron, millió Ft]. https:// www.ksh.hu/stadat_files/gdp/hu/gdpoo32.html (letöltve: 2021.09.30.).

Magyarország Kormánya (2017): A pénzügyi tudatosság fejlesztésének stratégiája. https://2015-2019. kormany.hu/download/5/39/2100o/P\%C3\%A9nz\%C3\%BCgyi\%2otudatoss\%C3\%A1g\%2o fejleszt\%C3\%A9s\%C3\%A9nek\%2ostrat\%C3\%A9gi\%C3\%A1ja.pdf (letöltve: 2021.09.30).

MihÁlyi PÉTER (1997): A bankprivatizáció tanulságai. Külgazdaság, 41(10), 61-68, ISSN 0324-4202, ZDB-ID 446481-3.

MNB (2020) Azonnali fizetési rendszer. https://www.mnb.hu/penzforgalom/azonnalifizetes.

MNB (2021a): MNB Pénzügyi Stabilitási Jelentés (2021. június). https://www.mnb.hu/kiadvanyok/ jelentesek/penzugyi-stabilitasi-jelentes/penzugyi-stabilitasi-jelentes-2021-junius (letöltve: 2021.09.30.).

MNB (2021b): Idősoros táblák szektoronként (SCV-k nélkül) - Az államháztartás és a háztartások előzetes pénzügyi számlái. https://www.mnb.hu/statisztika/statisztikai-adatok-informaciok/ adatok-idosorok/xii-a-nemzetgazdasag-penzugyi-szamlai-penzugyi-eszkozok-eskotelezettsegek-allomanyai-es-tranzakcioi/teljes-koru-minden-szektorra-vonatkozopenzugyi-szamlak/idosoros-tablak-szektoronkent-scv-k-nelkul.

Németh Erzsébet - Béres Dániel - Huzdik Katalin - Zsótér Boglárka (2016): Pénzügyi személyiségtípusok Magyarországon - kutatási módszerek és primer eredmények. Hitelintézeti Szemle, 15(2), 153-172. ISSN 1588-6883, http://real.mtak.hu/id/eprint/39312.

Németh ErzséBet (2022): A pénzügyi kultúrához kapcsolódó képzések. Összehasonlító elemzés (2016-2020). Gazdaság és Pénzügy, 9(1), 68-101, https://doi.org/10.33926/GP.2022.1.4.

OECD (2015): OECD/INFE Core competencies framework on financial literacy for youth https:// www.oecd.org/finance/Core-Competencies-Framework-Youth.pdf.

OECD (2020): OECD/INFE 2020 International Survey of Adult Financial Literacy. https://www. oecd.org/financial/education/launchoftheoecdinfeglobalfinancialliteracysurveyreport.htm.

PÁsztor Szabolcs (2018): The Future of Commercial Banks - Survival or Failure? Izvestiya - Mezhdunarodnyy teoreticheskiy i nauchno-prakticheskiy zhurnal, 23(4), 79-89. ISSN: 1694-7347,https://www.elibrary.ru/item.asp?id=36685133.

Pintér Éva (2020) Tendenciák a pénzügyi tudatosságban. http://www.fintelligence.hu/kiadvanyok/ TPT2020.pdf.

Poletaeva, V. - Perepelitsa, D. - Arhangel'skaya, T. - Zaripov, I. - Pásztor, Sz. (2019): The research task of banks and authorized government institution interests in manufacturing companies' investment projects congruence. International Journal of Mechanical Engineering and Technology, 10(2), 1603-1609. https://iaeme.com/MasterAdmin/Journal_uploads/IJMET/ VOLUME_10_ISSUE_2/IJMET_10_02_165.pdf.

Terták Elemér (2022): Pénzügyi oktatás a világban. Gazdaság és Pénzügy, 9(1), 20-49, https://doi. org/10.33926/GP.2022.1.2.

VÁRhegy I Éva (2019) A magyar bankrendszer felnőtté válásának története. Gazdaság és Pénzügy, 6(1), 39-55. https://www.bankszovetseg.hu/Public/gep/2019/039-55\%20varhegyi\%2oeva\%20 jav_doi.pdf.

Zsótér BoglárkA - Németh ErzséBet - Béres DÁNIEL (2016): A pénzügyi kultúra személyiség-, attitűd- és viselkedésbeli komponensei - Összehasonlító elemzés. Kultúra és Közösség, VII(III), 89-102. ISSN 0133-2597, http://real.mtak.hu/id/eprint/47835. 